\title{
Pengaruh Model Pembelajaran Problem Solving- Think Pair Share terhadap Pengetahuan Metakognitif Siswa
}

\author{
Sandi Limbanadi ${ }^{1}$, Subandi ${ }^{1}$, Munzil ${ }^{1}$ \\ ${ }^{1}$ Pendidikan Kimia-Universitas Negeri Malang
}

\begin{tabular}{l}
\hline INFO ARTIKEL \\
\hline Riwayat Artikel: \\
Diterima: $30-12-2019$ \\
Disetujui: $18-06-2020$ \\
\hline
\end{tabular}

\section{Kata Kunci:}

problem solving; think pair share; metacognitive knowledge; problem solving; think pair share; pengetahuan metakognitif

\author{
Alamat Korespondensi: \\ Sandi Limbanadi \\ Pendidikan Kimia \\ Universitas Negeri Malang \\ Jalan Semarang 5 Malang \\ E-mail: sandilimbanadi@gmail.com
}

\begin{abstract}
This study aims to determine the students' metacognitive knowledge chemistry students who study with Problem Solving-Think Pair Share Learning Models in the experimental class and problem solving learning models in the control class. The study uses a posttest control group design and sample selection uses convenience sampling techniques. Research data in the form of metacognitive knowledge test values measured from test questions in the form of essays each containing three types of metacognitive knowledge. The results has showed that there was a influence of learning models on students' metacognitive knowledge, this effect was seen from the existence of significant differences between students studying in the experimental class.
\end{abstract}

ABSTRAK

\begin{abstract}
Abstrak: Penelitian ini bertujuan untuk mengetahui pengetahuan metakognitif siswa kimia materi sifat koligatif larutan pada siswa yang belajar dengan model pembelajaran Problem Solving-Think Pair Share di kelas eksperimen dan model pembelajaran Problem Solving di kelas kontrol. Penelitian menggunakan desain Postest Control Group Design dan pemilihan sampel menggunakan teknik Convenience Sampling. Data penelitian berupa nilai tes pengetahuan metakognitif yang diukur dari soal tes berbentuk esai masing-masing berisi tiga jenis pengetahuan metakognitif. Hasil penelitian menunjukkan bahwa siswa yang belajar dengan model pembelajaran Problem SolvingThink Pair Share memiliki pengetahuan metakognitif yang lebih baik dibandingkan yang belajar dengan model Problem Solving.
\end{abstract}

Ilmu kimia terdiri dari konsep, teori, hukum, dan prinsip yang berkembang berdasarkan eksperimen dan penelitian (Wu, 2001) serta mendefinisikan banyak teori dan konsep-konsep yang menjelaskan bagaimana perubahan suatu zat terjadi (Effendy, 2017). Sampai saat ini pelajaran kimia masih sering disebut sebagai salah satu pelajaran yang dianggap sulit khususnya oleh siswa. Beberapa kendala dalam mempelajari kimia yaitu kesulitan dalam memahami konsep-konsep secara keseluruhan, kesulitan dalam masalah perhitungan algoritmik (Tuysuz, 2009), penyampaian informasi masih mendominasi (Permatasari, 2014) serta siswa tidak mengalami proses pembelajaran secara langsung (Chandrasegaran, Treagust, \& Mocerino, 2007). Dalam hal ini dapat disimpulkan bahwa kesulitan terjadi karena pembelajaran tidak memperhatikan karakter ilmu kimia sebagai proses untuk memahami konsep. Kesulitan dalam penguasaan konsep akan menyulitkan siswa pada materi berikutnya sebab dalam pelajaran kimia memiliki materi dengan urutan yang tersusun secara berjenjang. Hal ini mengakibatkan penyelesaian soal yang lebih kompleks akkan menjadi lebih sulit dan tidak terstruktur.

Materi kimia yang diajarkan di sekolah menegah salah satnya adalah materi sifat koligatif larutan dimana materi ini merupakan materi yang membahas konsep dan termasuk perhitungan. Hal tersebut menjadikan materi sifat koligatif larutan membutuhkan pemahaman konsep. Penjelasan materi kimia yang diungkapkan oleh (Ozgelen, 2012) yaitu meliputi sekumpulan kognisi fakta, konsep, dan prinsip. Jika siswa tidak mampu menguasai secara keseluruhan akan menyebabkan kesalahan bahkan miskonsepsi. Selain itu, beberapa materi sifat koligatif larutan bersifat pendekatan saintifik, sehingga membutuhkan strategi yang tepat (Ariyaldi, Putri, Khalisah, \& Nurhikmah, 2017). Oleh karena itu, proses pembelajaran dengan metode yang tepat harus dilaksanakan dengan baik.

Proses pembelajaran yang tidak melibatkan siswa berperan aktif dan menempuh proses yang tidak terstruktur akan menyebabkan siswa sulit menemukan pola untuk menyelesaikan suatu tugas dan berujung miskonsepsi. Miskonsep yang terjadi berakibat pada rendahnya kognisi seseorang. Hal ini terjadi kemungkinan karena kecenderungan siswa yang hanya sekedar menghapal pengetahuan sehingga hapalan itu tidak akan bertahan lama. Berdasarkan hasil uji coba soal materi SKL di salah satu SMA di Sulawesi Utara, diperoleh terbanyak siswa tidak mampu menyelesaikan soal mengenai konsentrasi larutan seperti konsep mol, molaritas, dan molalitas larutan sehingga menyulitkan siswa dalam meyelesaikan soal berikutnya yang lebih kompleks. Hal 
ini menuntut pemahaman terhadap konsep harus dapat dipenuhi terlebih dahulu. Tidak hanya itu, beberapa materi sifat koligatif larutan terdiri dari konsep yang abstrak (Chittleborough, Treagust, \& Mocerino, 2002), dan kimia adalah sebagai produk dari sekumpulan pengetahuan yang terdiri dari fakta, konsep beserta prinsipnya (Ozgelen, 2012). Hal tersebut menjadikan materi kimia dianggap sulit dan berakibat siswa cenderung menghapal (Dhindsa \& Treagust, 2012).

Kesulitan tersebut juga dialami siswa di Sekolah tempat pengambilan data oleh peneliti, rendahnya haasil belajar terlihat dari sedikitnya siswa yang mencapai nilai ketuntasan minimal yaitu hanya sekitar 29,8 \% dari 77 siswa. Hal ini diduga karena siswa cenderung menghapal dan tidak terlibat aktif dalam proses pembelajaran sehingga mengakibatkan siswa kesulitan dalam mengkonstruk suatu konsep. Berdasarkan hasil wawancara dengan guru mata pelajaran bahwa proses pembelajaran di kelas masih sering menggunakan pembelajaran konvensional dan kurang melibatkan siswa secara aktif.

Tuntutan pendidikan sekarang ini yaitu siswa harus mampu melibatkan berpikir tingkat tinggi yang melibatkan proses kognitif atau dengan kata lain pelibatann metakognitif (Livingston, 1997), dan kemampuan kerjasama untuk memecahkan masalah (Permendikbud, 2016). Akan tetapi, kenyataan di lapangan bahwa pembelajaran di sekolah belum dapat memberdayakan metakognitif siswa, sebagaimana hasil penelitian dari (Sholihah, Zubaidah, \& Mahanal, 2016) yang menyatakan bahwa pemberdayaan metakognitif masih tergolong rendah. Didukung pernyataan Corebima bahwa pemberdayaan penalaran di sekolah dasar dan menengah hampir tidak diperhatikan, guru telah mengarahkan siswa berperan aktif tetapi belum memberdayakan metakognitif siswa (Corebima, Zubaidah, \& Pangestuti, 2015). Berdasarkan uraian beberapa masalah di atas, perlu adaanya penggunaan suatu model pembelajaran agar siswa aktif mengkonstruk pengetahuan sebagai upaya untuk menghasilkan pencapaian belajar yang lebih baik.

Model pembelajaran yang dinilai dapat menjadikan siswa terlibat aktif salah satunya yaitu model problem solving yang terdiri dari prosedur pembelajaran berdasarkan perencanaan dan penalaran. Langkah-langkah yang diambil adalah langkahlangkah problem solving menurut G.Polya (Polya, 1973) yaitu (1) memahami masalah, (2) membuat rencana pemecahan masalah, (3) melaksanakan rencana pemecahan masalah, dan (4) mengevaluasi kembali hasil pemecahan. Tahapan tersebut menurut penelitian yang dilakukan oleh (Karatas \& Baki, 2013) bahwa dapat meningkatkan proses kognitif misalnya mencakup pemahaman konsep, keterampilan memecahkan masalah (Husna \& Fatimah, 2012), dan kemampuan terhadap pemecahan masalah (Broman, Bernholt, \& Parchmann, 2015). Hal tersebut sama dengan penelitian (Warimun, 2012) menyatakan bahwa pembelajaran menggunakan pemecahan masalah juga akan meningkatkan keberhasilan siswa dan kemampuan menjalankan metakognisi (Wicaksono, Widoretno, \& Nurmiyati, 2015). Berdasarkan beberapa keunggulan langkah pemebelajaran problem solving tersebut yang identik dengan pemberian masalah kepada siswa, maka diprediksi bahwa model tersebut dapat mengembangkan kemampuan dalam melibatkan proses kognitif siswa dalam mempelajari kimia pada materi sifat koligatif larutan atau dengan kata lain melibatkan metakognitif siswa. Oleh karena itu, model pembelajaran problem solving dinilai sangat cocok digunakan dalam penelitian ini.

Model pembelajaran Problem Solving memfasilitassi siswa untuk terlibat aktif dalam pembelajaran khususnya terkait dengan proses pemecahan masalah dalam pembelajaran. Akan tetapi, model ini mempunyai kelebihan dan kelemahan, yaitu (1) siswa yang pasif akan tertinggal, (2) memerlukan perencanaan yang matang dan teratur, (3) tidak efektif jika terdapat peserta didik yang pasif (Shoimin, 2014); (Sudjana, 2012). Selain itu, model ini melibatkan banyak orang sehingga terdapat tahapantahapan yang membuat siswa cenderung tidak berperan dalam proses pembelajaran. Artinya bahwa siswa yang pasif akan cenderung sulit dalam menyesuaikan dengan suatu masalah yang lebih rumit terutama pada tahap membuat rencana pemecahan dan penyelesaian masalah. Hal ini juga sejalan dengan (Novianti, 2011) dalam penelitiannya menyebutkan bahwa kelemahan PS yaitu terkait dengan pokok masalah yang diberi ke siswa, jika kompleksitas masalah tinggi dan individual maka akan menyebabkan rasa cemas bagi siswa. Wesson (2013) menyatakan bahwa dari empat langkah tersebut, tahapan tersulit dan paling rumit adalah tahap membuat rencana pemecahan dan melaksanakan perencanaan pemecahan sehingga siswa cenderung mengalami kesulitan dan mengakibatkan proses pemecahan masalah menjadi kurang maksimal. Mengingat kekurangan yang ada, upaya memfasilitasi siswa agar memiliki kemampuan yang baik untuk mencapai keberhasilan belajar salah satunya yaitu memberikan perlakuan pada tahapan problem solving yang masih ada kekurangan agar dapat meningkatkan aktifitas belajar siswa. Perlakuan yang dimaksud yaitu perlakuan yang meningkatkan pelibatan metakognitif kedalam proses pembelajaran (Thomas, 2014). Penjelasan lebih lanjut mengenai metakognitif adalah sebagai kesadaran dan pengelolaan proses kognitif (Ekoningtyas, 2013), sebagai perkusor untuk mengembangkan pemahaman materi, keterampilan proses sains, dan kemampuan bernalar ilmiah (G. Thomas, Anderson, \& Nashon, 2008). Beberapa penelitian menjelaskan bahwa keterlibatan aktifitas metakognitif dapat meningkatkan hasil belajar (Georghiades, 2006), berpengaruh pada kemampuan bertanya (Kaberman \& Judy, 2008), dan kemampuan metakognisi (Lestari \& Wijayanti, 2016). Hal ini menyebabkan pentingnya pemberdayaan metakognitif dalam suatu model pembelajaran sehingga aktifitas belajar siswa menjadi baik. Model pembelajaran yang dimaksudkan adalah pembelajaran kooperatif, dimana peneliti menduga bahwa hal ini dapat memberikan pengaruh baik terhadap aktifitas belajar siswa dan pemberdayaan metakognitif.

Salah satu model pembelajaran kooperatif yang berpotensi untuk memberdayakan metakognitif siswa dan meningkatkan hasil belajarnya adalah menggunakan pembelajaran Think Pair Share (Efendi, 2013), didukung penelitian Sele (2016) bahwa pembelajaran yang berbasis Think Pair Share lebih baik jika dibandingkan dengan pembelajaran konvensional karena dapat melatih dan meningkatkan keterampilan berpikir siswa (Tembang, 2017), Think Pair Share juga dilaksanankan dengan kelompok kecil sehingga partisipasi siswa meningkat (Sururoh \& Setyosari, 2018). Dengan demikian, pembelajaran Think Pair Share 
merupakan pembelajaran yang dapat bersinergi dengan problem solving sehingga interaksi siswa melalui aktivitas belajar siswa pada setiap tahapan problem solving dinilai akan menjadi lebih baik. Think Pair Share memiliki tahapan yang memberikan kesempatan dan waktu pada siswa untuk berpikir, menjawab, dan saling membantu dengan pasangannya kemudian diperkuat dengan berbagi pengetahuan antar kelompok dalam kelas.

Tahapan Think Pair Share terdiri dari tiga tahapan, yaitu tahap think yang mendorong siswa untuk berpikir cecara individu, tahap pair dilakukan dengan diskusi bersama pasangan, dan tahap share dilakukan untuk mendiskusikan pengetahuan yang diperoleh masing-masing kelompok ke kelompok yang lain. Jadi, Think Pair Share dengan tahapan tersebut cocok dipadukan dengan problem solving sehingga saling melengkapi setiap kekurangan dalam tiap tahapan yang telah dijabarkan di atas. Perpaduan ini diprediksi dapat meningkatkan hasil belajar siswa dan melibatkan kemampuan metakognitifnya.

\section{METODE}

Desain penelitian ini menggunakan rancangan eksperimen semu postest control group design dengan dua kelas dijadikan sampel penelitian yang dipilih dari populasi menggunakan teknik convenience sampling yaitu dengan mempertimbangkan kemampuan akademik siswa dan masukkan guru terkait kesesuaian jadwal dari kelas yang dijadikan sampel penelitian. Siswa SMA N 1 Bolaang dijadikan populasi dan diambil sampel penelitian yang terdiri dari kelas XII MIA 1 dibelajarkan dengan model problem solving-think pair share sebagai kelas eksperimen yang berjumlah 26 siswa dan XII MIA 3 dibelajarkan dengan model problem solving sebagai kelas control yang berjumlah 25 siswa. Variabel bebas dalam penelitian ini yaitu model pembelajaran dan variabel terikat yaitu pengetahuan metakognitif. Pengetahuan metakognitif diukur dengan instrumen berupa soal esay yang dibuat berdasarkan kriteria soal menurut Rompayon masing-masing terbagi menjadi tiga jenis pengetahuan, yaitu pengetahuan deklaratif, prosedural dan kondisional(Rompayom, Tambunchong, Wongyounoi, \& Dechsri, 2010). Teknik analisis data meliputi uji prasyarat dan uji hipotesis dimana uji prasyarat melalui uji normalitas data (uji Shapiro Wilk) dan uji homogenitas (uji Levene's test) sedangkan uji hipotesis melalui uji independent sample t-test. Analisis data tersebut menggunakan bantuan program SPSS 24.0 for windows dengan taraf kepercayaan $95 \%(\alpha=0,05)$.

\section{HASIL}

Data penelitian berupa hasil post-test pengetahuan metakognitif yang berasal dari dua kelas yang menjadi sampel penelitian, yaitu kelas PS-TPS dan kelas PS. Hasil post-test berupa nilai tes pengetahuan metakognitif yang ditampilkan dalam Tabel 1 .

Tabel 1. Data Nilai Tes Pengetahuan Metakognitif

\begin{tabular}{lcccc}
\hline \multirow{2}{*}{ Kelas } & \multicolumn{4}{c}{ Nilai Pengetahuan Metakognitif } \\
\cline { 2 - 5 } & N & Nilai rata-rata & Nilai maksimum & Nilai minimum \\
\hline Eksperimen $(P S-T P S)$ & 26 & 80,21 & 96 & 52 \\
\hline Kontrol $(P S)$ & 25 & 72,08 & 94 & 56 \\
\hline
\end{tabular}

Data yang tersebut pada tabel 1 menunjukkan bahwa di kelas eksperimen sebanyak 26 siswa memiliki nilai rata-rata 80,21 denagn nilai maksimum dan minimum berturut-turut 96 dan 52, sedangkan di kelas kontrol sebanyak 25 siswa memiliki nilai rata-rata 72,08 dengan nilai maksimum 94 dan nilai minimum 56. Hasil post-test kemudian dianalisis dengan program SPSS 24.0 yaitu uji komparasi menggunakan uji-t. Sebelum di analisis lebih lanjut, terlebih dahulu dilakukan uji prasyarat yaitu uji homogenitas data dan uji normalitas data. Hasil uji prasyarat dipaparkan pada tabel 2.

Tabel 2. Hasil Uji Prasyarat Normalitas dan Homogenitas Data

\begin{tabular}{lll}
\hline \multicolumn{1}{c}{ Hipotesis } & \multicolumn{1}{c}{ Kriteria Uji } & \multicolumn{1}{c}{ Hasil Uji } \\
\hline $\begin{array}{l}\text { Uji homogenitas } \\
\begin{array}{l}\mathrm{H}_{0}=\text { skor tes pengetahuan metakognitif kelas } \\
\text { eksperimen dan kelas kontrol homogeny }\end{array}\end{array}$ & $\begin{array}{l}\mathrm{H}_{0} \text { diterima jika nilai } \\
\text { signifikansi } \geq 0,05\end{array}$ & Nilai signifikansi $=0,933$ \\
\hline $\begin{array}{l}\text { Uji normalitas } \\
\begin{array}{l}\mathrm{H}_{0}=\text { skor tes pengetahuan metakognitif kelas } \\
\text { eksperimen dan kelas kontrol terdistribusi } \\
\text { normal }\end{array}\end{array}$ & $\begin{array}{l}\mathrm{H}_{0} \text { diterima jika nilai } \\
\text { signifikansi } \geq 0,05\end{array}$ & $\begin{array}{l}\text { Nilai signifikansi kelas eksperimen } \\
\text { homogen }\end{array}$ \\
\hline
\end{tabular}

Data pada tabel 2 menunjukkan bahwa hasil uji Levene's test dengan nilai signifikansi 0,933 lebih besar dari 0,05 yang berarti data skor pengetahuan metakognitif siswa materi sifat koligatif larutan memiliki variasi yang sama atau homogen. Hasil uji Shapiro Wilk dengan nilai signifikansi kelas eksperimen $=0,105$ dan kelas kontrol = 0,346 lebih besar dari 0,05 yang berarti data kedua kelas terdistribusi normal. Kesimpulan dari analisis tersebut bahwa uji prasyarat terpenuhi dan analisis lanjut untuk hipotesis dapat dilanjutkan. Uji hipotesis menggunakan uji-t dengan program SPSS 24.0 menunjukkan bahwa ada pengaruh model pembelajaran PS-TPS terhadap pengetahuan metakognitif siswa. Hasil uji-t dipaparkan pada tabel 3. 
Tabel 3. Hasil Uji-T Independent Sample T-test

\begin{tabular}{llll}
\hline \multicolumn{1}{c}{ Hipotesis } & Kriteria Uji & Hasil Uji \\
\cline { 3 - 4 } & & $\begin{array}{l}\text { Nilai } \\
\mathrm{t}_{\text {hitung }}\end{array}$ & Kesimpulan \\
\hline $\begin{array}{l}\mathrm{H}_{1}=\text { ada perbedaan pengetahuan metakognitif siswa } \\
\text { pada materi sifat koligatif larutan }\end{array}$ & $\begin{array}{l}\mathrm{H}_{1} \text { diterima jika thitung } \\
\text { untuk df } 49=2,000\end{array}$ & $\begin{array}{l}\mathrm{H}_{1} \text { diterima, ada perbedaan } \geq \mathrm{t}_{\text {tabel }} \\
\text { yang signifikan }\end{array}$ \\
\hline
\end{tabular}

Data pada tabel 3 menunjukkan nilai $t_{\text {hitung }}$ lebih besar dari $\mathrm{t}_{\text {tabel }}$ yang berarti terdapat perbedaan pengetahuan metakognitif secara signifikan antara kedua kelas eksperimen dan kontrol.

\section{PEMBAHASAN}

Analisis data penelitian menunjukkan terdapat perbedaan yang signifikan antara pengetahuan metakognitif siswa yang belajar dengan PS-TPS dan yang PS saja. Perbedaan disebabkan oleh beberapa fakor dalam sintaks pembelajaran PS-TPS. Siswa dalam kelas eksperimen menempuh serangkaian prosedur sebelum siswa mengkonstruk pengetahuan. Pemberian waktu tunggu pada siswa di tahapan think dalam problem solving memberikan kesempatan bagi siswa untuk menggunakan kemampuan berpikirnya sehingga siswa secara keseluruhan cenderung tidak pasif. Aktivitas yang sering diberikan kepada siswa tersebut akan menyebabkan siswa terbiasa menerima pengalaman untuk memikirkan jawaban, sehingga memberi kemudahan untuk mengingat kembali pengetahuan yang dikonstruk dan dideklarasikan menjadi suatu pengetahuan yang lengkap.

Tahap pair dalam problem solving memberikan kesempatan siswa untuk saling merespon jawaban yang diperoleh masing-maisng. Sehingga siswa membangun pengetahuan dari hasil konstruk pengetahuan yang dibuat pada tahapan sebelumnya. Hasil ini didukung oleh (Tiantong \& Sumalee, 2013) dan Kagan (2009) yang menyatakan bahwa aktivitas berpasangan mengakibatkaan siswa berusaha untuk mengungkapkan pendapat dan mencari jawaban yang tepat. Pada tahapan ini juga dapat membangun partisipasi masing-maisng siswa dan pengetahuannya lebih dalam. Hal ini juga didukung oleh Chotimah (2017) bahwa siswa yang mendapatkan kesempatan yang sama dalam mengungkapkan pendapat dan membangun pengetahuan menyebabkan siswa yang belajar dengan model pembelajaran PS-TPS memiliki produk kognitif yang mendalam.

Pada tahap share dalam problem solving siswa saling berbagi jawaban, setiap pasangan dalam kelompoknya berbagi jawaban dengan kelompok lain sehingga kesempatan ini memberikan pola yang terstruktur bagi siswa. Sehingga mampu memberikan kesempatan siswa untuk memiliki kognisi yang runtut dan sistematis yang berdampak pada struktur kognitif yang telah dibangun pada tahapan sebelumnya akan semakin baik. Pendapat ini didukung oleh (Anita. S \& Azizah, 2016) yang menyatakan bahwa sebenarnya beberapa konsep yang relevan telah ada dalam struktur kognitif siswa, kognitif tersebut akan semakin baik jika didukung dengan pengetahuan baru yang diperoleh dari sharing dengan teman kelompok.

Pengetahuan deklaratif siswa yang belajar di kelas eksperimen lebih unggul daripada siswa yang belajar di kelas kontrol yaitu terlihat dari adanya perbedaan yang signifikan pengetahuan metakognitif antara kedua kelas. Hal ini menandakan bahwa ada pengaruh model pembelajaran PS-TPS terhadap pengetahuan metakognitifnya. Capaian terlihat pada nilai rata-rata pengetahuan deklaratif siswa di kelas eksperimen dan kontrol berturut-turut yaitu 81 dan 77 . Kebanyakan siswa pada kelas eksperimen memiliki kemampuan mencari informasi yang terdapat dalam soal untuk selanjutnya diselesaikan. Hal tersebut juga memberikan kemudahan bagi siswa di kelas eksperimen memberikan penjelasan misalnya terkait akibat terjadinya penurunan tekanan uap larutan. Kemampuan tersebut juga terlihat melalui capaian pengetahuan deklaratif siswa dimana sebanyak $23 \%$ menjawab benar dengan skor penuh, lebih tinggi dibandingkan siswa di kelas kontrol yang hanya sekitar 16,0\%.

Pengetahuan prosedural siswa di kelas eksperimen dan kelas kontrol rata-rata memberikan kemampuan yang relatif sama, capaian tersebut terlihat dari nilai rata-rata siswa di kedua kelas yaitu 87 dan 85 . Capaian ini juga didukung dengan persentase perolehan sebaran skor siswa yang belajar dengan PS-TPS maupun yang belajar dengan PS yang memperoleh jawaban benar dengan skor penuh yaitu berturut-turut sebanyak 34,6\% dan 40,0\%. Artinya bahwa baik siswa di kelas eksperimen maupun di kelas kontrol memiliki pengetahuan prosedural yang baik. Kesimpulam tersebut memberikan gambaran yang memperkuat bahwa siswa yang belajar dengan kedua model pembelajaran yang digunakan memiliki kemampuan yang runtut dan sistematis disebabkan karena siswa terbiasa memahami kimia melalui sudut pandang algoritmik.

Pengetahuan kondisional siswa yang belajar dengan PS-TPS lebih baik dari siswa dengan pembelajaran PS saja. Ratarata nilai pengetahuan kondisional siswa di kelas PS-TPS yaitu 87 yang lebih tinggi daripada rata-rata nilai di kelas PS yaitu 63. Pola sebaran skor siswa terlihat bahwa sebagaian besar siswa yang belajar menggunakan PS-TPS mampu menyelesaikan tugas dengan baik. Misalnya sebanyak 38,5\% siswa di kelas eksperimen mampu menentukan hasil tekanan osmotik air laut yang diketahui dari data komponen penyusun air lautnya. Capaian tersebut sangat besar dibandingkan siswa yang belajar di kelas kontrol yang hanya sekitar 8,0\% yang mampu menjawab benar. 


\section{SIMPULAN}

Berdasarkan hasil analisis data dan pembahasan, disimpulkan bahwa ada pengaruh model pembelajaran problem solvingthink pair share terhadap pengetahuan metakognitif siswa dalam mempelajari kimia pada materi sifat koligatif larutan. Siswa yang dibelajarkan dengan model PS-TPS mempunyai pengetahuan metakognitif yang lebih tinggi dibandingkan yang dibelajarkan dengan model PS.

Mengacu pada hasil penelitian, maka saran yang dapat diberikan adalah bahwa (a) pembelajaran di kelas sebaiknya menggunakan model pembelajaran yang sesuai dengan materi pembelajaran, dalam hal ini disarankan menggunakan model pembelajaran PS-TPS karena terbukti memberikan pengaruh baik terhadap pengetahuan metakognitif siswa, dan (b) hasil penelitian ini dapat dijadikan acuan bagi peneliti lain untuk meneliti efektifitas model PS-TPS pada mata pelajaran yang lain.

\section{DAFTAR RUJUKAN}

Anita. S, T., \& Azizah, U. (2016). Penerapan Model Pembelajaran Kooperatif Tipe Think Pair Share untuk Melatih Keterampilan Metakognitif Siswa Pada Materi Reaksi Reduksi dan Oksidasi. UNESA Journal of Chemical Education, 5(2), 381-391.

Ariyaldi, Putri, A. T., Khalisah, A. N., \& Nurhikmah. (2017). Pengaruh Penggunaan Strategi Dynamic Problem Solving Berbasis Conceptual Scaffolding untuk Meningkatkan Hasil Belajar dan Aktivitas Belajar Peserta Didik pada Materi Sifat Koligatif Larutan. Jurnal Nalar Pendidikan, 5, 158-164.

Broman, K., Bernholt, S., \& Parchmann, I. (2015). Analysing Task Design and Students' Responses to Context-Based Problems Through Different Analytical Frameworks. Research in Science and Technological Education, 33(2), $143-161$.

Chandrasegaran, A. L., Treagust, D. F., \& Mocerino, M. (2007). The Development of a Two-Tier Multiple-Choice Diagnostic Instrument for Evaluating Secondary School Students' Ability to Describe and Explain Chemical Reactions Using Multiple Levels of Representation. Chemistry Education Research and Practice, 8(3), 293-307.

Chittleborough, G. D., Treagust, D. F., \& Mocerino, M. (2002). Constraints to the Development of First Year University Chemistry Students' Mental Models of Chemical Phenomena. 11th Annual Teaching and Learning Forum for Western Australian Universities, (1982), 43-50.

Chotimah, C. (2017). Pengembangan Modul Biologi dengan Strategi Pembelajaran Think Pair Share sebagai Upaya Meningkatkan Motivasi Belajar, Sikap Sosial, Kemampuan Berpikir Kritis, dan Hasil Belajar Kognitif Siswa SMK Kota Malang. Disertasi tidak diterbitkan. Universitas Negeri Malang, Malang.

Corebima, A. D., Zubaidah, S., \& Pangestuti, A. A. (2015). Using Reading-Concept Map-Teams Games Tournament (RemapTGT) to Scientific Inquiry in Lecture View project Remap Coople View project Using Reading-Concept Map-Teams Games Tournament (Remap-TGT) to Improve Reading Interest of Tenth Grade Student of Laborat. American Journal of Educational Research, 3(2), 250-254.

Dhindsa, H. S., \& Treagust, D. F. (2012). Conceptual Understanding of Bruneian Tertiary Students: Chemical Bonding and Structure. Brunei International Journal Os Science \& Mathematic Education, 1(1), 33-51.

Efendi, N. (2013). Pengaruh Pembelajaran Reciprocal Teaching Dipadukan Think Pair Share terhadap Peningkatan Kemampuan Metakognitif Belajar Biologi Siswa. Jurnal Santiaji Pendidikan, 3(2), 85-105.

Effendy. (2017). Molekul, Struktur dan Sifat-sifatnya. Publishing, Indonesian Academic.

Ekoningtyas, M. (2013). Pengaruh Pembelajaran Think-Pair-Share dipadu Pola Pemberdayaan Berpikir melalui Pertanyaan terhadap Keterampilan Metakognitif, Berpikir Kreatif, Pemahaman Konsep IPA dan Retensinya serta Sikap Sosial. Jurnal Pendidikan Sains, 1(4), 332-342.

Georghiades, P. (2006). The Role of Metacognitive Activities in the Contextual Use of Primary Pupils' Conceptions of Science. Research in Science Education, 36, 29-30.

Hamdani. (2011). Strategi Pembelajaran. Pustaka Setia.

Husna, I. M., \& Fatimah, S. (2012). Peningkatan Kemampuan Pemecahan Masalah dan Kemampuan Matematis Siswa Sekolah Menengah Pertama melalui Model Pembelajaran Think Pair Share. Jurnal Peluang, 1(2), 81-92.

Kaberman, Z., \& Judy, Æ. Y. (2008). Metacognition in Chemical Education : Question Posing in the Case-Based Computerized Learning Environment. Springer Science, 37, 403-436.

Karatas, I., \& Baki, A. (2013). The Effect of Learning Environments Based on Problem Solving on Students' Achievements of Problem Solving. International Electronic Journal of Elementary Education, 5(3), 249-267.

Kuhn, D., \& Dean, D. (2004). A Bridge Between Cognitive Psychology and Educational Practice. Theory into Practice, 43(4), 268-273.

Lestari, P. B., \& Wijayanti, T. (2016). Pengaruh Model Reciprocal Teaching Dipadukan dengan Think Pair Share terhadap Kemampuan Metakognisi Mahasiswa. Jurnal Edukasi Matematika dan Sains, 4(1), 36-42.

Novianti, D. (2011). Pengaruh Penerapan Model Pembelajaran Cooperative Problem Solving dan Cooperative Problem Posing terhadap Kualitas Proses Kognitif dan Hasil Belajar untuk Pokok Bahasan Termodinamika Kimia. Tesis tidak diterbitkan. Universitas Negeri Malang, Malang.

Ozgelen, S. (2012). Students' Science Process Skills within a Cognitive Domain Framework. Eurasia Journal of Mathematics, Science and Technology Education, 8(4), 283-292. 
Permatasari, R. E. (2014). Implementasi Model Pembelajaran Inkuiri Terbimbing pada Materi Sifat Koligatif Larutan. Jurnal Pena Sains, 1(2), 2407-2311.

Rompayom, P., Tambunchong, C., Wongyounoi, S., \& Dechsri, P. (2010). The Development of Metacognitive Inventory to Measure Students' Metacognitive Knowledge Related to Chemical Bonding Conceptions. International Association for Education Asessment, (Iaea), 1-7. Retrieved from http://selectscore.com/fullpaper/221.pdf

Sele, Y. (2016). Analisis Potensi Think Pair Share dalam Pemberdayaan Keterampilan Metakognitif Siswa Laki-laki dan Perempuan. Bioedu, 4(1), 13-22.

Shoimin, A. (2014). Model Pembelajaran Inovatif dalam Kurikulum 2013. Yogyakarta: Ar-Ruzz Media.

Sholihah, M., Zubaidah, S., \& Mahanal, S. (2016). Memberdayakan Keterampilan Metakognitif Dan Hasil Belajar Kognitif Siswa Dengan Model Pembelajaran Reading Concept Map-Reciprocal Teaching (Remap Rt). Jurnal Pendidikan: Teori, Penelitian, dan Pengembangan, 1(4), 628-633.

Sudjana, N. (2012). Cara Belajar Siswa Aktif dalam Proses Belajar Mengajar. Bandung: Sinar Baru Algensindo.

Sururoh, M., Setyosari, P., \& Subanji. (2018). Pengaruh Model Pembelajaran Think Pair Share terhadap Pemahaman Konsep dan Motivasi Belajar. Jurnal Pendidikan: Teori, Penelitian, dan Pengembangan, 3(11), 1499-1506.

Tembang, Y., Sulton., \& Suharjo. (2017). Peningkatan Motivasi dan Hasil Belajar Melalui Model Pembelajaran Think Pair Share Berbantuan Media Gambar. Jurnal Pendidikan: Teori, Penelitian, dan Pengembangan, 2(6), 812-817.

Thomas, G., Anderson, D., \& Nashon, S. (2008). Development of an Instrument Designed to Investigate Elements of Science Students' Metacognition, Self-Efficacy and Learning Processes : The SEMLI-S. International Journal of Science Education, 30(13), 1701-1724.

Thomas, G. P. (2014). Changing the Metacognitive Orientation of a Classroom Environment to Stimulate Metacognitive Reflection Regarding the Nature of Physics Learning. International Journal of Science, 35(7), 37-41.

Tiantong, P., \& Sumalee, S. (2013). The Online Project-based Learning Model Based on Student's Multiple Intelligence. International Journal of Humanities and Social Science, 3(7), 204-211.

Tuysuz, C. (2009). Development of Two-Tier Diagnostic Instrument and Assess Students' Understanding in Chemistry. Scientific Research and Essays, 4(6), 626-631.

Warimun, E. (2012). Penerapan Model Pembelajaran Problem Solving Fisika Pada Pembelajaran Topik Optika Pada Mahasiswa Pendidikan Fisika. Exacta, 10(2), 111-114.

Wicaksono, A. R., Widoretno, S., \& Nurmiyati. (2015). Pengaruh Penggunaan Modul Berbasis Research pada Pembelajaran Think Pair Share dan Group Investigation terhadap Pemahaman Konsep dan Kemampuan Metakognisi Peserta Didik Kelas X SMA Negeri 1 Boyolali Tahun Ajaran 2013/2014. Jurnal Bioedukasi, 8(1), 60-66.

Wu, D. (2001). Promoting Understanding of Chemical Representations: Students' Use of a Visualization Tool in the Classroom. Journal of Research in Science Teaching, 38(7), 821-842. 